\title{
PENINGKATAN KEMAMPUAN MEMBACA PUISI MELALUI PEMODELAN PADA SISWA KELAS VII A SMP NEGERI 16 KOTA BENGKULU
}

\author{
Anes Marta Swara Utami, Agus Joko Purwadi, dan M. Arifin \\ Program Studi Pendidikan Bahasa Indonesia \\ Jurusan Pendidikan Bahasa dan Seni \\ FKIP Universitas Bengkulu \\ anesmartaswarautami@gmail.com
}

\begin{abstract}
Abstrak
Penelitian ini bertujuan untuk meningkatkan kemampuan membaca puisi siswa kelas VII A SMP Negeri 16 Kota Bengkulu dengan menerapkan metode pemodelan. Jenis penelitian yang digunakan adalah penelitian tindakan kelas. Penelitian ini dilaksanakan dalam dua siklus. Teknik pengumpulan data menggunakan teknik observasi dan tes kerja siswa. Data yang diperoleh pada siklus I yaitu 13 siswa yang tuntas dan 19 siswa belum tuntas, dengan persentase ketuntasan klasikal sebesar 40,6\%. Pada siklus II, 24 siswa memperoleh nilai tuntas dan 8 siswa masih belum tuntas dengan persentase ketuntasan klasikal 75\% meningkat sebanyak $34,4 \%$ dari siklus I. Hasil penelitian ini menunjukkan adanya peningkatan kemampuan membaca puisi siwa yang dilihat dari aspek pemahaman, ekspresi dan mimik, intonasi, pelafalan, serta penampilan dan kinesik. Berdasarkan hasil tersebut, metode pemodelan sangat baik untuk diterapkan dalam pembelajaran membaca puisi.
\end{abstract}

Kata Kunci: Membaca puisi, peningkatan, pemodelan

\begin{abstract}
This study aims to improve the ability to read poetry for students of class VII A of SMP Negeri 16 Kota Bengkulu by applying the modeling method. The type of this research used is classroom action research. This study was conducted in two cycles. Techniques of collection data were observation techniques and student work tests. The data obtained in the first cycle were 13 students who were completed and 19 students had not yet completed, with the percentage of classical completeness of $40.6 \%$. In the second cycle, 24 students got complete scores and 8 students were still incomplete with a percentage of $75 \%$ classical completeness increased by $34.4 \%$ from cycle I. The results of this study showed an increase in the ability to read poetry from the aspects of understanding, expression, intonation, pronunciation, and appearance and performance. Based on these results, modeling methods was appropriate to be applied in the reading poetry learning.
\end{abstract}

Keywords: Reading poetry, improvement, modeling

\section{PENDAHULUAN}

Membaca puisi tidak sama halnya saat seseorang membaca koran atau membaca buku, karena bahasa dalam puisi lebih padat dan penuh dengan gaya bahasa yang terkadang memiliki banyak makna, sehingga sebelum membaca puisi, siswa harus benar-benar siap dan memahami betul makna puisi yang akan dibacakan. Membaca puisi termasuk jenis membaca 
estetis, yaitu kegiatan membaca yang dilatarbelakangi tujuan menikmati serta menghargai unsur-unsur keindahan yang terpapar dalam suatu teks sastra (Aminuddin, 2014:20).

Puisi sendiri menurut Nurhadi (2016:106) merupakan karya sastra yang berisi gagasan penyair dengan bahasa yang padat, singkat, dan menggunakan irama dengan bunyi yang padu dan pemilihan kata-kata kias (imajinatif). Sedangkan menurut Pradopo (2002:7), puisi itu mengekspresikan pemikiran yang membangkitkan perasaan, yang merangsang imajinasi panca indera dalam susunan yang berirama.

Dalam membaca puisi, seorang pembaca puisi harus memperhatikan beberapa hal yang dianggap penting agar pembacaan puisi menjadi indah. Aminuddin (2014:29) menyatakan ada tiga unsur utama yang harus diperhatikan sewaktu membaca puisi yaitu (1) pemahaman, seorang pembaca puisi harus paham betul seluk-beluk puisi yang akan dibacakan. Tidak hanya memahami teks puisi, namun harus menjiwai puisi yang akan dibacakan. (2) penghayatan, sama halnya dengan memahami puisi, menghayati puisi juga tak lepas dari persoalan makna puisi. Membaca puisi bukan hanya sekedar membacakan teks puisi, pembaca puisi juga harus mampu menyampaikan isi puisi. (3) pemaparan, saat membacakan puisi seorang pembaca harus memperhatikan kualitas bunyi atau intonasi yang berkaitan dengan kuat-lunak, tinggi-rendahnya bunyi ujaran yang diujarkan. Tempo, yaitu pengaturan cepatlambatnya pengujaran. Pelafalan berkaitan dengan cara mengucapkan bunyi ujaran secara tepat, kuat, dan jelas. Ekspresi berkaitan dengan air muka yang ditampilakn seorang pembaca, serta pembaca juga harus memperhatikan pandangan mata, pengaturan posisi tubuh atau dengan pengaturan gerak-gerik tubuh. Sedangkan menurut Sumardi
(2013:118), beberapa hal teknis yang berkaitan dengan baca sajak atau puisi yang perlu diperhatikan antara lain: olah vokal, gerak atau akting, olah ruang dan properti, serta komunikasi hati dengan penonton.

Berdasarkan wawancara yang dilakukan dengan guru mata pelajaran bahasa Indonesia di sekolah, kemampuan membaca puisi siswa masih tergolong rendah. Siswa hanya membacakan puisi tanpa memerhatikan intonasi, ekspresi, penghayatan, dan lain-lain. Siswa beranggapan bahwa pembelajaran membaca puisi terlalu sulit. Bahasa yang digunakan oleh penulis sukar untuk dipahami oleh siswa, sehingga saat siswa diminta untuk membacakan puisi di depan kelas, siswa kurang menghayati puisi yang dibaca. Selain itu, kepercayaan diri siswa masih kurang. Siswa masih terlihat malumalu untuk mengekspresikan puisi yang dibaca, bahkan terkadang siswa menutupi muka dengan teks puisi yang dibaca. Siswa juga tidak memerhatikan intonasi atau tinggi rendah, keras atau lembutnya suara saat membacakan puisi, sehingga irama saat siswa membacakan puisi masih monoton. Selain itu, pelafalan kata-kata dalam puisi masih kurang jelas.

Oleh sebab itu, guru dituntut untuk mampu merancang pembelajaran yang merangsang siswa untuk mengembangkan kemampuan membaca puisinya. Guru juga dituntut untuk mampu melaksanakan pembelajaran yang aktif, siswa diharapkan terlibat langsung dalam pembelajaran. Melalui keterlibatan secara langsung, diharapkan siswa memperoleh pengalaman dan pemahaman terhadap membaca puisi.

Pembelajaran membaca puisi sendiri dilaksanakan di kelas VII pada semester genap dengan standar kompetensi 15 . membaca sastra, membaca wacana sastra melalui kegiatan membaca puisi dan buku cerita anak pada kompetensi dasar 15.1 yaitu membaca 
indah puisi dengan menggunakan irama, volume suara, mimik, kinestik sesuai dengan isi puisi.

Dalam pembelajaran membaca puisi, guru harus memberikan kesempatan siswa untuk mengembangan kemampuan membaca puisinya, salah satunya dengan menerapkan metode pemodelan. Melalui pemodelan, siswa memiliki ruang yang cukup untuk mencoba dan mengembangkan keterampilan yang diajarkan. Pemodelan adalah adalah proses pembelajaran dengan memperagakan sesuatu sebagai contoh yang dapat ditiru oleh setiap siswa (Sanjaya, 2013:267-268).

Belajar melalui pemodelan, siswa bukan hanya sekedar mendengarkan dan mencatat, tetapi belajar melalui pengalaman secara langsung. Dengan adanya model yang didatangkan secara langsung ke dalam kelas, pengetahuan siswa terhadap membaca puisi akan lebih nyata. Hal ini sejalan dengan kerucut pengalaman yang dikemukakan oleh Edgar Dale (dalam Sanjaya, 2013:168) bahwa siswa akan lebih konkret memperoleh pengetahuan melalui pengalaman langsung, melaui benda-benda tiruan, melalui pemeranan drama, demonstrasi atau peragaaan dan pemeranan.

Berdasarkan hal inilah, maka penulis tertarik untuk melakukan penelitian dengan bagaimanakah peningkatan kemampuan membaca puisi siswa kelas VII A SMP Negeri 16 Kota Bengkulu melalui pemodelan?

\section{METODE}

Rancangan penelitian yang digunakan dalam penelitian ini adalah Penelitian Tindakan Kelas (Classroom Action Research) yang mengacu pada model Kemmis dan Mc Taggart yang dikembangkan oleh Stephen Kemmis dan Robert Mc Taggart. Penelitian tindakan ini dilaksanakan dalam beberapa siklus hingga siklus ke-n sampai tercapainya kriteria penelitian.

Teknik pengumpulan data dalam penelitian ini yaitu observasi dan tes kinerja. Observasi digunakan untuk mengetahui pelaksanaan pembelajaran membaca puisi di kelas VII A SMP Negeri 16 Kota Bengkulu. Tes pengukuran digunakan untuk mengetahui bagaimana hasil pembelajaran membaca puisi setelah dilaksanakannya pembelajaran dengan metode pemodelan, apakah metode tersebut mampu meningkatkan hasil pembelajaran membaca puisi atau tidak.

\section{HASIL DAN PEMBAHASAN \\ Hasil}

Perencanaan pelaksanaan tindakan diawali dengan menyiapkan rencana pelaksanaan pembelajaran (RPP) dengan menerapkan metode pemodelan, menyusun lembar penilaian dan indikator penilaian, memilih puisi yang akan dijadikan bahan ajar dalam pembelajaran, dan menyiapkan media pembelajaran. Dalam pembelajaran dengan metode pemodelan ini, media yang digunakan adalah model. Model yang mencontohkan membaca puisi pada penelitian ini adalah Eko Purwandi yang sudah sering memenangkan kejuaraan membaca puisi. Pada siklus ke-1 ini, bahan ajar yang digunakan yaitu puisi karya Chairil Anwar dengan judul Diponegoro.

Berdasarkan pelaksanaan tindakan pada siklus ke-1 diperoleh rata-rata nilai kemampuan membacapuisi siswa sebesar 70,9 dengan persentase ketuntasan klasikal kemampuan membaca puisi siswa sebesar $40,6 \%$ yang berarti baru 13 dari 32 siswa yang memeroleh nilai di atas kriteria ketuntasan minimal, sedangkan 19 siswa memperoleh nilai di bawah kriteria ketuntasan minimal (KKM).

Tabel 1. Rekapitulasi Nilai Kemampuan Membaca Puisi Siklus Ke-1 


\begin{tabular}{|l|l|}
\hline \multicolumn{1}{|c|}{ Keterangan } & \multicolumn{1}{c|}{ Siklus I } \\
\hline Nilai Tertinggi & 85 \\
\hline Nilai Terendah & 55 \\
\hline Nilai Rata-Rata & 70,9 \\
\hline $\begin{array}{l}\text { Presentase Ketuntasan } \\
\text { Klasikal }\end{array}$ & $40,6 \%$ \\
\hline
\end{tabular}

Hasil pengamatan atau observasi pada siklus ke-1 ini yaitu, siswa mendengarkan pemaparan guru tentang tujuan pembelajaran. Saat proses pemodelan berlangsung, siswa sangat antusias dan memperhatikan model membacakan puisi dengan serius. Namun, saat kegiatan diskusi berlangsung ada beberapa siswa yang tidak mengikuti diskusi dengan baik, beberapa diantaranya tidak memperhatikan temannya membacakan puisi. Saat diminta membacakan puisi di depan kelas, masih ada beberapa siswa yang belum berani tampil.

Pelaksanaan siklus ke-2 merupakan tindak lanjut dari hasil refleksi siklus ke-1. Pelaksanaan tindakan siklus ke-2 diharapkan menjadi lebih baik. Perencanaan pelaksanaan tindakan siklus ke-2 diawali dengan menyiapkan rencana pelaksanaan pembelajaran (RPP) dengan menerapkan metode pemodelan, menyusun lembar penilaian dan indikator penilaian, memilih puisi yang akan dijadikan bahan ajar dalam pembelajaran, dan menyiapkan media pembelajaran. Dalam pembelajaran dengan metode pemodelan ini, media yang digunakan adalah model. Model pada siklus ini masih sama dengan siklus sebelumnya yaitu, Eko Purwandi. Pada siklus ke-2, siswa diberikan beberapa pilihan puisi yaitu Doa karya Chairil Anwar, Alamku Indnesia karya Bambang Lukito,dan Ah Alamku Semakin Cemar karya Lita Hardono. Pemilihan puisi ini lebih divariasikan agar siswa dapat memilih puisi yang ia suka untuk memudahkan siswa memahami makna puisi tersebut.

Hasil tes kemampuan membaca puisi siswa pada siklus ke-2, rata-rata nilai siswa adalah 76,8 dan persentase ketuntasan klasikal membaca puisi siswa sebesar 75\% yang berarti 24 dari 32 siswa yang memeroleh nilai di atas kriteria ketuntasan minimal, sedangkan 8 siswa masih memperoleh nilai di bawah kriteria ketuntasan minimal (KKM).

Tabel 2. Rekapitulasi Nilai Kemampuan Membaca Puisi Siklus Ke-2

\begin{tabular}{|l|c|}
\hline \multicolumn{1}{|c|}{ Keterangan } & Siklus II \\
\hline Nilai Tertinggi & 91 \\
\hline Nilai Terendah & 62 \\
\hline Nilai Rata-Rata & 76,8 \\
\hline $\begin{array}{l}\text { Presentase } \\
\text { Ketuntasan Klasikal }\end{array}$ & $75 \%$ \\
\hline
\end{tabular}

Jika dilihat dari aspek-aspek membaca puisi yaitu aspek pemahaman atau penghayatan, aspek ekspresi atau mimik, aspek intonasi, aspek pelafalan, dan aspek penampilan atau kinesik, perolehan skor rata-rata siswa seperti pada tabel berikut:

Tabel 3. Rata-rata Skor Aspek MembacaPuisi

\begin{tabular}{|c|l|c|c|}
\hline \multirow{2}{*}{ No. } & \multicolumn{1}{|c|}{ Aspek } & \multicolumn{2}{c|}{ Skor Rata-rata } \\
\cline { 3 - 4 } & \multicolumn{1}{|c|}{$\begin{array}{c}\text { Siklus } \\
\text { Ke-1 }\end{array}$} & $\begin{array}{c}\text { Siklus } \\
\text { Ke-2 }\end{array}$ \\
\hline 1. & $\begin{array}{l}\text { Aspek Pemahaman } \\
\text { atau } \\
\text { Penghayatan }\end{array}$ & 16,5 & 18,09 \\
\hline 2. & $\begin{array}{l}\text { Aspek Ekspresi atau } \\
\text { Mimik }\end{array}$ & 16,5 & 18,2 \\
\hline 3. & Aspek Intonasi & 14,9 & 15,8 \\
\hline 4. & Aspek Pelafalan & 11,9 & 12,8 \\
\hline 5. & $\begin{array}{l}\text { Aspek Penampilan atau } \\
\text { Kinesik }\end{array}$ & 10,8 & 11,7 \\
\hline
\end{tabular}

Dari tabel di atas, dapat diketahui bahwa rata-rata skor setiap aspek penilaian kemampuan membaca puisi mengalami peningkatan. Aspek pemahaman atau penghayatan mengalami peningkatan sebesar 1,59 dari siklus ke-1 
dengan rata-rata 16,5 menjasi 18,09 pada siklus ke-2. Rata-rata skor pada aspek ekspresi atau mimik pada siklus ke-1 yaitu 16,5 dan pada siklus ke-2 meningkat menjadi 18,2. Pada siklus ke-1 rata-rata skor aspek intonasi adalah 14,9 mengalami peningatan sebesar 0,9 menjadi 15,8 pada siklus ke-2. Rata-rata aspek pelafalan pada siklus ke-2 yaitu 12,8 meningkat sebanyak 0,9 dari siklus ke-1 dengan rata-rata 11,9. Sedangkan aspek penampilan atau kinesik meingkat sebanyak 0,9 menjadi 11,7 pada siklus ke-2 dari rata-rata 10,8 pada siklus ke-1.

\section{Pembahasan}

Berdasarkan hasil penelitian ini dapat dilihat bahwa terjadi peningkatan rata-rata nilai kemampuan membaca puisi siswa. Rata-rata nilai pada siklus ke-2 mengalami peningkatan sebesar 5,9 menjadi 76,8 dari rata-rata nilai 70,9 pada siklus ke-1. Selain itu persentase ketuntasan minimal pun mengalami peningkatan. Hasil pelaksanaan tindakan siklus ke-1 menunjukan 13 siswa mampu memperoleh nilai di atas kriteria ketuntasan minimal. Sedangkan 19 siswa lain masih masuk dalam kategori tidak tuntas, yang berarti baru $40,6 \%$ siswa memperoleh nilai tuntas. Setelah dilaksanakan penelitian siklus ke-2, diperoleh 24 siswa yang termasuk dalam kategori tuntas atau $75 \%$ dari 32 siswa. Dengan hasil tersebut terjadi peningkatan hasil kemamuan membaca puisi siswa sebesar 34,4\%.

Jika dilihat dari rata-rata skor setiap aspek penilaian kemampuan membaca puisi juga mengalami peningkatan. Setiap aspek yaitu aspek pemahaman atau penghayatan, aspek ekspresi atau mimik, aspek intonasi, aspek pelafalan, dan aspek penampilan atau kinesik mengalami peningkatan dan termasuk pada katerogi baik.
Ada pun temuan dalam penelitian ini yaitu:

1. Rata-rata nilai dan persentase ketuntasan klasikal mengalami peningkatan.

2. Rata-rata skor pada setiap aspek membaca puisi siswa mengalami peningkatan.

3. Dengan adanya pemodelan, siswa menjadi lebih aktif dan antusias dalam mengikuti pembelajaran. Model yang didatangkan ke dalam kelas mampu menarik perhatian siswa.

4. Kesempatan siswa untuk mengembangkan kemampuan membaca puisinya lebih besar, karena siswa diberikan kesempatan untuk membacakan puisi di dalam kelompok kecil terlebih dahulu.

Selain itu, dari penelitian ini juga ditemukan bahwa pemahaman siswa terhadap puisi berbeda-beda. Hal ini sesuai dengan pendapat Bandura (dalam Rahyubi, 2016-106) pengaruh seorang model tergantung pada kemampuan individu untuk mengingat tindakan model itu sesudah dia hilang dari pandangan.

\section{PENUTUP}

\section{Kesimpulan}

Hasil penelitian Peningkatan Kemampuan Membaca Puisi Melalui Pemodelan pada Siswa Kelas VII A SMP Negeri 16 Kota Bengkulu dapat disimpulkan bahwa penerapan metode pemodelan dalam pembelajaran membaca puisi dapat meningkatkan hasil belajar membaca puisi. Hal tersebut dapat dilihat dari peningkatan ketuntasan belajar pada siklus ke-1 hanya 13 siswa atau 40,6\% yang memperoleh nilai di atas kriteria ketuntasan minimal meningkat menjadi 24 siswa atau $75 \%$ yang memperoleh nilai tuntas di atas KKM. Selain itu rata-rata nilai juga mengalami peningkatan menjadi 76,8 pada siklus ke-2 dari rata-rata pada siklus ke-1 70,9. 


\section{Saran}

Dari hasil penelitian di atas, maka dapat diberikan saran sebagai berikut:

1. Bagi siswa; setelah pembelajaran membaca puisi melalui pemodelan ini dilaksanakan diharapkan siswa bisa lebih menyukai dan menggemari puisi baik di dalam kelas maupun di luar kelas, serta dapat meningkatkan kemampuan membaca puisi.

2. Bagi guru; dalam pembelajaran hendaknya guru bisa memaksimalkan penerapan metode pembelajaran dan penggunaan media pembelajaran sehingga meningkatkan kualitas pembelajaran. Selain itu, guru juga hendaknya mampu memotivasi dan menumbuhkan minat belajar puisi pada siswa.

\section{DAFTAR ISI}

Aminuddin. 2014. Pengantar Apresiasi Karya Sastra. Bandung: Sinar Baru Algesindo.

Nurhadi. 2016. Teknik Membaca. Jakarta: PT Bumi Aksara.

Rahyubi, Heri. 2016. Teori-teori Belajar dan Aplikasi Pembelajaran Motorik. Majalengka: Penerbit Referens.

Sanjaya, Wina. 2013. Strategi Pembelajaran Berorientasi Standar Proses Pendidikan. Jakarta: Kencana.

Sumardi. 2013. Panduan Apresiasi Puisi. Jakarta: Uhamka Press.

Pradopo, Rachmat Djoko. 2002. Pengkajian Puisi. Yogyakarta: Gadjah Mada University Press. 